\title{
Characterization of composted chicken manures discharged from farms in South Korea
}

\author{
Xuan Phuc Nguyen ${ }^{1,2}$, Hoon Jho', Yeon-Jae Jeong ${ }^{1}$, Young-Tae Jo ${ }^{1}$, Mohammad Nazrul Islam ${ }^{1,3}$, Jeong-Hun Park ${ }^{1,3^{\dagger}}$ \\ ${ }^{1}$ Department of Environment and Energy Engineering, Chonnam National University, Gwangju 500-757, Republic of Korea \\ ${ }^{2}$ Research Institute for Marine Fisheries, Hai Phong 180000, Vietnam \\ ${ }^{3}$ Environmental Assessment Research Institute, Gwangju 500-757, Republic of Korea
}

\section{ABSTRACT}

In this study, the characteristics as well as the maturity and stability of chicken manure collected from nine chicken farms in South Korea during the summer and winter seasons of 2014 are evaluated. The physicochemical parameter values of the manure, such as $\mathrm{BOD} \mathrm{NO}_{3}-\mathrm{N}$ and $\mathrm{PO}_{4}-\mathrm{P}$ etc. were determined using the Korea Standard test Method, HPLC, and APHA standard methods. The results showed that the alkalinity content and COD concentration in winter chicken manure were higher than those of summer chicken manure. The moisture content of summer manure was positively correlated with almost all of the other parameters of the manure, whereas it was negatively correlated with almost all of the other parameters in the winter manure. According to the criterion of $\mathrm{C} / \mathrm{N}$ ratio, chicken manure indicated good quality compost However, composted chicken manure showed immature and unstable compost when considering the criteria of the $\mathrm{NH}_{4}-\mathrm{N} / \mathrm{NO}_{3}-\mathrm{N}$ ratio and $\mathrm{NH}_{4}-\mathrm{N}$ concentrations.

Keywords: Chicken manure, Concentration, Correlation, Maturity, Stability

\section{Introduction}

The poultry population is increasing every year, causing an increase in the amount of remaining manure [1]. In addition, poultry contamination is a typical agricultural waste and has become a major source of rural pollution, while chicken manure has become the main source of poultry waste [2].

Composted animal manures (such as farmyard manure and chicken manure) represent a valuable resource, if managed appropriately; they are excellent fertilizers for crops and forages, and can be used to replace significant amounts of mineral fertilizers [3-5]. Chicken manure increases the electrical conductivity (EC) and cation exchange capacity (CEC) of soil, and the growth of cantaloupe cultivars, silage maize, and mentha spicata [6-8]. On the other hand, livestock and poultry manures containing a high proportion of biodegradable organic matter, nutrients, and pathogens have potential negative impacts on the environment [2, 9]. Leaching of nitrate and possible pathogens transferred to the ground water from manure storage facilities or from fields are particular threats to drinking water quality [10]. Qing Liao et al. [11] estimated the loss of biochemical oxygen demand $\left(\mathrm{BOD}_{5}\right)$, chemical oxygen demand (COD), and ammonia nitrogen $\left(\mathrm{NH}_{4}-\mathrm{N}\right)$ of livestock and poultry manure, and assumed that these contaminants were a considerable threat to the water environment. Moreover, the application of unstable and immature compost manure can affect nitrogen immobilization in the soil, restrict plant growth, and cause phytotoxic effects [12-15]. Therefore, in order to deal with these problems, several researchers have assessed the quality of composted manures, which were then appropriately applied for the best productivity and to protect the environment based on the physicochemical parameter properties of the composts [1, 8, 11]. The study of the value of the parameters in chicken manure is fundamental for providing a database for adequate use for crops and pollution control.

The aim of this study was to analyze the parameter contents and to determine the characteristics of composted chicken manure samples collected from nine farms in South Korea during the summer and winter seasons of 2014.

\section{Materials and Methods}

\subsection{Manure Sample Collection}

Composted chicken manure samples were collected from 9 farms 
located in South Korea during the summer and winter of 2014. One sample from each farm was taken randomly from 4 to 6 holes in the manure store location, then mixed and kept in a plastic bag.

\subsection{Sample Preparation and Analysis}

The samples were air-dried, ground to pass through a $0.1 \mathrm{~mm}$ sieve and treated with distilled water at a manure to water ratio of $1: 10(\mathrm{w} / \mathrm{v})$ in a $50 \mathrm{ml}$ plastic conical tube. The tube was tightly capped and shaken at $200 \mathrm{rpm}$ for 48 hours. The liquid samples were then used to analyze the $\mathrm{COD}, \mathrm{BOD}$, nitrate nitrogen $\left(\mathrm{NO}_{3}-\mathrm{N}\right)$, $\mathrm{NH}_{4}-\mathrm{N}$, phosphate phosphorus $\left(\mathrm{PO}_{4}-\mathrm{P}\right)$ and total kjeldahl nitrogen (TKN). The moisture content, total organic carbon (TOC), COD, BOD, total nitrogen (T-N), and total phosphorus (T-P) were analyzed using the Korea Standard Test Method [16].

The concentration of $\mathrm{NO}_{3}-\mathrm{N}$ and $\mathrm{PO}_{4}-\mathrm{P}$ were analyzed using high performance liquid chromatography (HPLC) with a conductivity detector (WATER 432, column Allsep Anion $7 \mu \mathrm{m}$ GRACE), a Mobile Phase (with suppresser) $0.85 \mathrm{mM}$ sodium bicarbonate $\left(\mathrm{NaHCO}_{3}\right)$, and a $0.9 \mathrm{mM}$ sodium carbonate $\left(\mathrm{Na}_{2} \mathrm{CO}_{3}\right)$ solution. The concentrations of $\mathrm{NH}_{4}-\mathrm{N}$, TKN, and alkalinity were analyzed according to American Public Health Association (APHA) standard methods [17].

\subsection{Statistical Analysis}

Statistical analysis was conducted using R software (version 3.1.2). The differences between the values of parameters in the winter manure and summer manure were tested using the t-test at a significant level of $5 \%$. The relationships between the physicochemical parameters in chicken manures were determined using the correlation analysis method.

\section{Results and Discussion}

\subsection{Physicochemical Properties of Composted Chicken Manure}

The moisture content in the summer chicken manure and in the winter chicken manure from farms in South Korea ranged from $14.18 \%$ to $78.74 \%$ with a mean of $26.90 \%$ and from $12.70 \%$ to $81.00 \%$ with a mean value of $38.40 \%$, respectively, while the content of alkalinity in the winter manure with a mean of $76,570 \mathrm{mg} / \mathrm{kg}$ was significantly $(p<0.05)$ higher than that in the summer manure with a mean value of $46,116 \mathrm{mg} / \mathrm{kg}$. A familiar trend with alkalinity was observed. The COD concentrations in chicken manure in winter (ranging from $344,000 \mathrm{mg} / \mathrm{kg}$ to $424,000 \mathrm{mg} / \mathrm{kg}$ with a mean of $388,444 \mathrm{mg} / \mathrm{kg}$ ) was significantly $(p<0.05$ ) higher than the concentration of COD in the summer chicken manure, which ranged from $224,000 \mathrm{mg} / \mathrm{kg}$ to $328,000 \mathrm{mg} / \mathrm{kg}$ with a mean of $279,111 \mathrm{mg} / \mathrm{kg}$. It is clear that under the effect of temperature, the evaporation of water in manure in the summer is higher than that of in the winter; thus, the moisture content of manure in winter was higher than that in summer. The higher alkalinity content of manure in winter than that in summer clearly reflects the general tendency that alkalinity (high $\mathrm{pH}$ ) in a lower temperature condition is usually higher than that in a higher temperature [18]. According to Wenche
Bergland et al. [19], the temperature significantly influences manure quality during storage. Dissolved organics are generated by the disintegration and hydrolysis of particles during storage in the warmest season, but not at winter temperatures. Therefore, organic matters of composted chicken manure in South Korea were dissolved and a greater amount of organic matter was lost in summer than in winter, resulting in a higher COD concentration of manure in winter than that in summer.

Related to the group of nitrogen, organic carbon, and phosphorous nutrients, $\mathrm{PO}_{4}-\mathrm{P}$ concentrations ranged from $2,798 \mathrm{mg} / \mathrm{kg}$ to $24,253 \mathrm{mg} / \mathrm{kg}$, whereas the T-P contents ranged from 11,263 $\mathrm{mg} / \mathrm{kg}$ to $32,735 \mathrm{mg} / \mathrm{kg}$. TOC contents in different types of chicken manures fluctuated in a narrow range, around $300,000 \mathrm{mg} / \mathrm{kg}$, while the concentrations of $\mathrm{NO}_{3}-\mathrm{N}$ and $\mathrm{NH}_{4}-\mathrm{N}$ widely fluctuated from $166 \mathrm{mg} / \mathrm{kg}$ to $1,546 \mathrm{mg} / \mathrm{kg}$ and from $259 \mathrm{mg} / \mathrm{kg}$ to 10,213 $\mathrm{mg} / \mathrm{kg}$, respectively. The TKN concentrations ranged from 8,138 $\mathrm{mg} / \mathrm{kg}$ to $36,856 \mathrm{mg} / \mathrm{kg}$ and the T-N contents ranged from 25,220 $\mathrm{mg} / \mathrm{kg}$ to $75,330 \mathrm{mg} / \mathrm{kg}$. Nitrogen $(\mathrm{N})$ and phosphorus $(\mathrm{P})$ are indispensable for sustainability in agriculture [20, 21]. They have been shown to improve soil fertility and enhance crop productivity $[8,22,23]$. However, the use of an inappropriate application rate can cause environmental risks $[11,20]$. For these reasons, in order to prevent and reduce risks to human health and the environment, in some countries such as Austria and Belgium, regulations have been established for the maximum amount of nitrogen supply using compost $(290 \mathrm{~kg} \mathrm{~N} / \mathrm{ha}$ in crop soil and $350 \mathrm{~kg} \mathrm{~N} / \mathrm{ha}$ in pastures, 800 - $100 \mathrm{~kg} \mathrm{~N} / \mathrm{ha}$ in crops with the addition of inorganic fertilization, and $250 \mathrm{~kg} \mathrm{~N} / \mathrm{ha}$ in maize crops). In other countries, preventive measures have even established for P input (Sweden 22-35 kg/ha per year and Denmark, $20 \mathrm{~kg} / \mathrm{ha}$ per year) [14]. Therefore, composted chicken manure from farms in South Korea needs to be calculated and applied appropriately for different types of soils, plants, and crops in order to gain the best productivity as well as protect the environment.

Correlation coefficients $(r)$ were compared between the physicochemical parameters of composted chicken manure. These are presented in Table 1 and Table 2 and in Fig. 1 and Fig. 2. It is noted that no significant correlation was observed between alkalinity and almost all other parameters in the summer chicken manure, while TOC correlated with the other parameters except for $\mathrm{NO}_{3}-\mathrm{N}$. The moisture content showed the closest correlation with T-P $(r=0.73)$, the second closest with $\mathrm{NH}_{4}-\mathrm{N}(r=0.68)$ and the third closest with $\mathrm{PO}_{4}-\mathrm{P}(r=0.62)$. COD was significantly correlated with the $\mathrm{C} / \mathrm{N}$ ratio $(r=0.76)$ (Table 1 and Fig. 1).

The concentration of $\mathrm{PO}_{4}-\mathrm{P}$ in winter chicken manure only correlated with T-P ( $r=0.79$ ) (Table 2 and Fig. 2). Moisture content was strongly, positively correlated with $\mathrm{C} / \mathrm{N}$ ratio $(r=0.8)$ and significantly, negatively correlated with alkalinity $(r=-0.60)$, BOD $(r=-0.63), \mathrm{NH}_{4}-\mathrm{N}(r=-0.50)$, TKN $(r=-0.72)$, and T-N $(r=$ -0.77). Thus, an increase in moisture content increases the $\mathrm{C} / \mathrm{N}$ ratio, but the value of alkalinity, BOD, $\mathrm{NH}_{4}-\mathrm{N}, \mathrm{TKN}$, and $\mathrm{T}-\mathrm{N}$ will decrease, and vice versa. A significant negative correlation was observed between alkalinity and $\mathrm{C} / \mathrm{N}$ ratio $(r=-0.70)$, whereas alkalinity was positively correlated with $\mathrm{NH}_{4}-\mathrm{N}(r=0.78)$ and $\mathrm{T}-\mathrm{N}(r=0.72)$.

It is interesting to note that the moisture content of manure in summer was positively correlated with almost all of the other 
parameters (Table 1), while it was negatively correlated with almost all of the other parameters in the winter season (Table 2). This result has been considered to be the consequence of temperature and effective microorganism (EM) activity [24]. The activity of EM results in a higher content of $\mathrm{N}, \mathrm{P}$, and $\mathrm{K}$ etc. in compost manure [25]. The higher moisture content of manure in the warm

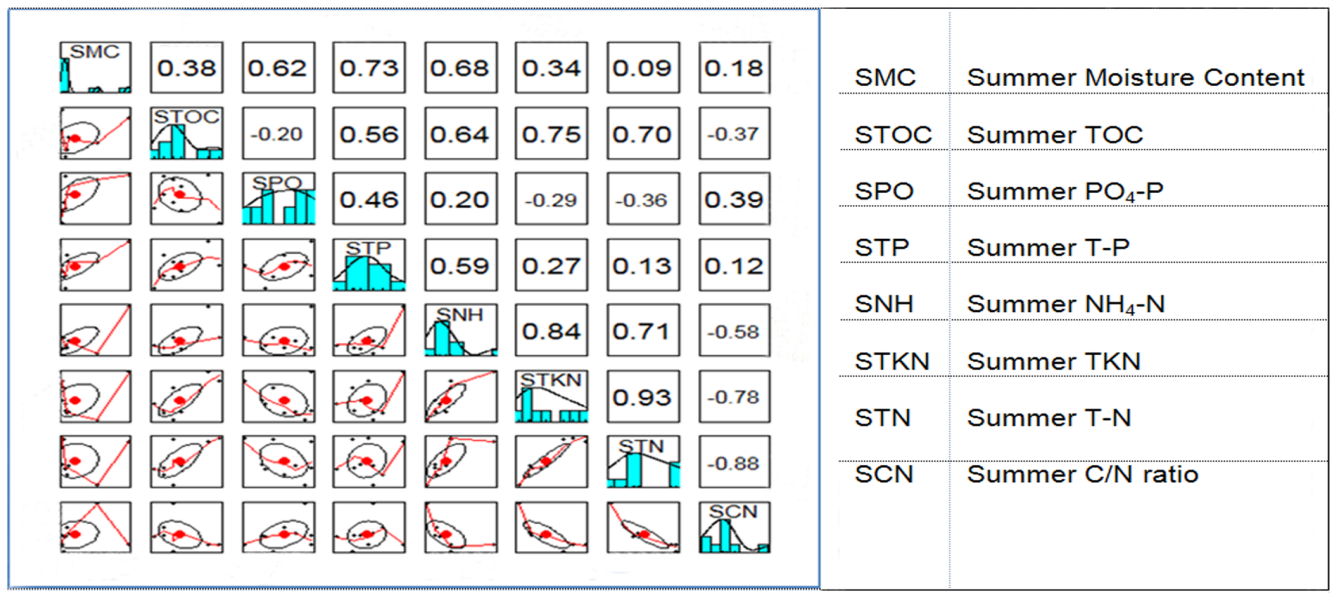

Fig. 1. Relationships between physiochemical parameters in summer chicken manure samples collected from nine farms in South Korea in 2014.

\begin{tabular}{|c|c|c|c|c|c|c|c|c|c|}
\hline WMc & -0.60 & -0.63 & -0.06 & -0.50 & -0.72 & -0.77 & 0.80 & WMC & Winter Moisture Content \\
\hline & & 0.15 & -0.32 & 0.78 & 0.29 & 0.72 & -0.70 & WAK & Winter Alkalinity \\
\hline & & & 0.45 & 0.28 & 0.78 & 0.41 & -0.22 & WBOD & Winter BOD \\
\hline & & & wcos & -0.03 & 0.08 & -0.19 & 0.42 & WCOD & Winter COD \\
\hline & & & & WNH & 0.54 & 0.84 & -0.60 & WNH & Winter $\mathrm{NH}_{4}-\mathrm{N}$ \\
\hline & & & & & & & & WTKN & Winter TKN \\
\hline & & & & & & & & WTN & Winter T-N \\
\hline & & & 3 & 60 & & N & -0.90 & WCN & Winter $\mathrm{C} / \mathrm{N}$ ratio \\
\hline & & & (6) & 2 & & & WCN & & \\
\hline
\end{tabular}

Fig. 2. Relationships between physiochemical parameters in winter chicken manure samples collected from nine farms in South Korea in 2014.

Table 1. Correlations Matrix between Physicochemical Parameters in Summer Chicken Manure Samples

\begin{tabular}{|c|c|c|c|c|c|c|c|c|c|c|c|c|}
\hline & MC & AK & BOD & COD & TOC & $\mathrm{PO}_{4}-\mathrm{P}$ & T-P & $\mathrm{NO}_{3}-\mathrm{N}$ & $\mathrm{NH}_{4}-\mathrm{N}$ & TKN & T-N & $\mathrm{C} / \mathrm{N}$ ratio \\
\hline $\mathrm{MC}$ & - & 0.39 & n.s & 0.33 & 0.38 & 0.62 & 0.73 & n.s & 0.68 & 0.34 & n.s & n.s \\
\hline $\mathrm{AK}$ & & - & -0.22 & n.s & -0.25 & n.s & 0.37 & -0.31 & n.s & n.s & n.s & n.s \\
\hline BOD & & & - & n.s & 0.85 & -0.55 & n.s & -0.24 & 0.28 & 0.60 & 0.59 & -0.28 \\
\hline COD & & & & - & 0.21 & 0.22 & 0.36 & 0.62 & -0.24 & -0.37 & -0.53 & 0.76 \\
\hline TOC & & & & & - & -0.20 & 0.56 & n.s & 0.64 & 0.75 & 0.70 & -0.37 \\
\hline $\mathrm{PO}_{4}-\mathrm{P}$ & & & & & & - & 0.46 & 0.28 & 0.20 & -0.29 & -0.36 & 0.39 \\
\hline T-P & & & & & & & - & -0.26 & 0.59 & 0.27 & n.s & n.s \\
\hline $\mathrm{NO}_{3}-\mathrm{N}$ & & & & & & & & - & -0.40 & -0.52 & -0.51 & 0.47 \\
\hline $\mathrm{NH}_{4}-\mathrm{N}$ & & & & & & & & & - & 0.84 & 0.71 & -0.58 \\
\hline $\mathrm{TKN}$ & & & & & & & & & & - & 0.93 & -0.78 \\
\hline $\mathrm{T}-\mathrm{N}$ & & & & & & & & & & & - & -0.88 \\
\hline $\mathrm{C} / \mathrm{N}$ & & & & & & & & & & & & - \\
\hline
\end{tabular}

*samples were collected from nine farms in South Korea in 2014 at a significant $p<0.05$ n.s: not significant, MC: moisture content, AK: alkalinity. 
Table 2. Correlations Matrix between Physicochemical Parameters in Winter Chicken Manure Samples

\begin{tabular}{|c|c|c|c|c|c|c|c|c|c|c|c|c|}
\hline & MC & AK & BOD & COD & TOC & $\mathrm{PO}_{4}-\mathrm{P}$ & T-P & $\mathrm{NO}_{3}-\mathrm{N}$ & $\mathrm{NH}_{4}-\mathrm{N}$ & TKN & $\mathrm{T}-\mathrm{N}$ & $\mathrm{C} / \mathrm{N}$ ratio \\
\hline $\mathrm{MC}$ & - & -0.60 & -0.63 & n.s & -0.20 & n.s & 0.24 & n.s & -0.50 & -0.72 & -0.77 & 0.80 \\
\hline $\mathrm{AK}$ & & - & $\mathrm{n} . \mathrm{s}$ & -0.32 & -0.29 & -0.31 & n.s & -0.32 & 0.78 & 0.29 & 0.72 & -0.70 \\
\hline BOD & & & - & 0.45 & 0.74 & -0.29 & -0.52 & 0.70 & 0.94 & 0.78 & 0.41 & -0.22 \\
\hline COD & & & & - & 0.74 & n.s & -0.58 & 0.32 & 0.35 & n.s & n.s & 0.42 \\
\hline TOC & & & & & - & n.s & -0.34 & 0.58 & 0.65 & 0.48 & n.s & n.s \\
\hline $\mathrm{PO}_{4}-\mathrm{P}$ & & & & & & - & 0.79 & -0.28 & -0.24 & n.s & n.s & n.s \\
\hline T-P & & & & & & & - & -0.50 & -0.36 & n.s & n.s & -0.29 \\
\hline $\mathrm{NO}_{3}-\mathrm{N}$ & & & & & & & & - & 0.52 & 0.53 & n.s & 0.25 \\
\hline $\mathrm{NH}_{4}-\mathrm{N}$ & & & & & & & & & - & 0.54 & 0.84 & -0.60 \\
\hline $\mathrm{TKN}$ & & & & & & & & & & - & 0.80 & -0.64 \\
\hline $\mathrm{T}-\mathrm{N}$ & & & & & & & & & & & - & -0.90 \\
\hline $\mathrm{C} / \mathrm{N}$ & & & & & & & & & & & & - \\
\hline
\end{tabular}

*Samples were collected from nine farms in South Korea in 2014 at a significant $p<0.05$.

n.s: not significant, MC: moisture content, AK: alkalinity.

summer temperature leads to an increase in EM growth as well as a greater EM activity. This results in higher contents of $\mathrm{PO}_{4}-\mathrm{P}$, T-P, $\mathrm{NH}_{4}-\mathrm{N}$, and TKN, etc. of the manure in this study. This is why moisture content was positively correlated with almost all other parameters. In contrast, in the cold conditions in winter, if the moisture content in the manure is higher, the temperature of the manure is lower, and the EM activity in manure is thus restricted. This phenomenon causes lower contents of TOC, $\mathrm{NH}_{4}-\mathrm{N}$, TKN, and TN, etc. in the manure. This indicates a negative correlation between moisture content and the content of various parameters in winter manure.

\subsection{Assessment of Maturity and Stability of Composted Chicken Manure}

In relation to compost, stability and maturity are two terms usually used to describe the rates of the decomposition and transformation of the organic matter in the compost. Compost maturity is used to describe product quality, while compost stability is strongly related to the rate of microbial activity in the compost [26]. In a number of researches, the $\mathrm{C} / \mathrm{N}$ ratio is used as an index of compost stability as well as an indicator of compost maturity [12, 27]. In the present study, the $\mathrm{C} / \mathrm{N}$ ratios ranged from 4.07 in summer layer manure at farm L-4 to 13.90 in the winter layer of manure at farm L-3 (Table 3). According to Bernal et al. [12] and Iglesias-Jiménez and Pérez-García [28], a C/N ratio lower than 12 after the composting process indicated a good degree of maturity and suitability for addition to soil. Moreover, almost all the $\mathrm{C} / \mathrm{N}$ ratios in the manure samples in this research were found to be lower than 12, indicating that the manure can be considered as ready to be applied. Only the $\mathrm{C} / \mathrm{N}$ ratio in winter layer manure at farm L-3 (13.90) was higher than 12 , indicating that the compost manure at this farm was unstable.

Besides the $\mathrm{C} / \mathrm{N}$ ratio, the $\mathrm{NH}_{4}-\mathrm{N} / \mathrm{NO}_{3}-\mathrm{N}$ ratio and $\mathrm{NH}_{4}-\mathrm{N}$ concentrations are used as indexes for assessing compost stability and compost maturity. The value of $\mathrm{NH}_{4}-\mathrm{N} / \mathrm{NO}_{3}-\mathrm{N}<0.16$ denoted very stable or mature compost [12]. In this study, the $\mathrm{NH}_{4}-\mathrm{N} / \mathrm{NO}_{3}-\mathrm{N}$ ratios ranged from 1.44 to 91.31 , which did not meet the requirement for the degree of maturity of less than 0.16 . This means that the
Table 3. $\mathrm{C} / \mathrm{N}$ Ratio and $\mathrm{NH}_{4}-\mathrm{N} / \mathrm{NO}_{3}-\mathrm{N}$ Ratio in Broiler Chicken Manure and Layer Chicken Manure

\begin{tabular}{|c|c|c|c|c|}
\hline \multirow{2}{*}{ Farm } & \multicolumn{2}{|c|}{$\mathrm{C} / \mathrm{N}$ ratio } & \multicolumn{2}{|c|}{$\mathrm{NH}_{4}-\mathrm{N} / \mathrm{NO}_{3}-\mathrm{N}$ ratio } \\
\hline & SBM & WBM & SBM & WBM \\
\hline B-1 & 6.35 & 7.70 & 6.59 & - \\
\hline B-2 & 6.62 & 8.70 & 10.70 & 10.37 \\
\hline B-3 & 5.00 & 6.45 & 49.92 & 3.97 \\
\hline L-1 & 10.93 & 10.84 & 3.56 & - \\
\hline $\mathrm{L}-2$ & 7.51 & 6.33 & 12.09 & - \\
\hline L-3 & 5.02 & 13.90 & 91.31 & 1.44 \\
\hline $\mathrm{L}-4$ & 4.07 & 4.23 & - & - \\
\hline L-5 & 6.41 & 7.39 & 4.30 & - \\
\hline L-6 & 6.25 & 6.58 & - & - \\
\hline
\end{tabular}

*The broiler chicken manure and layer chicken manure collected from nine farms in South Korea in summer and winter in 2014

-: cannot be calculated, SBM: summer broiler manure, WBM: winter broiler manure, SLM: summer layer manure, WLM: winter layer manure.

compost manures in all farms were unstable and immature. However, the California Compost Quality Council (CCQC) [29] categorizes mature compost into three levels based on the $\mathrm{NH}_{4}-\mathrm{N} / \mathrm{NO}_{3}-\mathrm{N}$ ratios: $\mathrm{NH}_{4}-\mathrm{N} / \mathrm{NO}_{3}-\mathrm{N}<0.5$ (very mature), $0.5 \leq$ $\mathrm{NH}_{4}-\mathrm{N} / \mathrm{NO}_{3}-\mathrm{N} \leq 3.0$ (mature), and $\mathrm{NH}_{4}-\mathrm{N} / \mathrm{NO}_{3}-\mathrm{N}>3.0$ (immature). Compared to the $\mathrm{NH}_{4}-\mathrm{N} / \mathrm{NO}_{3}-\mathrm{N}$ ratios in this research, only the $\mathrm{NH}_{4}-\mathrm{N} / \mathrm{NO}_{3}-\mathrm{N}$ ratio in winter layer manure at farm L-3 (1.44) showed that the compost had reached a mature level, whereas the other $\mathrm{NH}_{4}-\mathrm{N} / \mathrm{NO}_{3}-\mathrm{N}$ ratios showed that the compost was at an immature level. However, Rui Guo et al. [15] suggested that the $\mathrm{NH}_{4} / \mathrm{NO}_{3}$ ratio may not be suitable as a maturity index for manure composts, and this should be further studied. On the other hand, a high concentration of $\mathrm{NH}_{4}-\mathrm{N}$ in a compost indicates instability [30]. According to Zucconi and de Bertoldi [31], the maximum $\mathrm{NH}_{4}-\mathrm{N}$ concentration in a mature compost should be less than $400 \mathrm{mg} / \mathrm{kg}$. In the present study, the concentration of $\mathrm{NH}_{4}-\mathrm{N}$ in winter layer manure at farm L-1 $(259 \mathrm{mg} / \mathrm{kg})$ was less than $400 \mathrm{mg} / \mathrm{kg}$, while the others were higher. Therefore, only winter layer manure at 
farm L-1 reached a maturity level for compost according to the $\mathrm{NH}_{4}-\mathrm{N}$ concentration criterion $(<400 \mathrm{mg} / \mathrm{kg})$.

In general, the composted chicken manures in the present study were not ready for use when considering the criteria of the $\mathrm{NH}_{4}-\mathrm{N} / \mathrm{NO}_{3}-\mathrm{N}$ ratios and the $\mathrm{NH}_{4}-\mathrm{N}$ concentration. Stable and mature compost can be used to enhance soil fertility and plant growth. In contrast, the application of unstable and immature compost can fix nitrogen in the soil, restrict plant growth, and cause phytotoxic effects [12-15]. In this research, the $\mathrm{NH}_{4}-\mathrm{N} / \mathrm{NO}_{3}-\mathrm{N}$ ratios and the concentrations of $\mathrm{NH}_{4}-\mathrm{N}$ were high, while the $\mathrm{NH}_{4}-\mathrm{N}$ concentrations were obviously higher than the $\mathrm{NO}_{3}-\mathrm{N}$ concentrations. Even the concentrations of $\mathrm{NO}_{3}-\mathrm{N}$ in winter layer chicken manure at farm B-1, farm L-1, farm L-2, farm L-4, farm L-5, and farm L-6 were not detected. The $\mathrm{NH}_{4}-\mathrm{N} / \mathrm{NO}_{3}-\mathrm{N}$ ratio and $\mathrm{NH}_{4}-\mathrm{N}$ concentrations are still high, indicating that nitrification is not complete [12]. The nitrification process oxidizes $\mathrm{NH}_{4}-\mathrm{N}$ to $\mathrm{NO}_{2}-\mathrm{N}$ and then $\mathrm{NO}_{3}-\mathrm{N}$ during composting, which leads to a decrease in $\mathrm{NH}_{4}-\mathrm{N}$ and an increase in $\mathrm{NO}_{3}-\mathrm{N}$; thus, the $\mathrm{NH}_{4}-\mathrm{N} / \mathrm{NO}_{3}-\mathrm{N}$ ratio is lower in mature compost [12, 15, 27, 32, 33]. Hence, the chicken manure in farms in South Korea needs to be composted longer and the $\mathrm{NH}_{4}-\mathrm{N} / \mathrm{NO}_{3}-\mathrm{N}$ ratio and the concentration of $\mathrm{NH}_{4}-\mathrm{N}$ should be decreased to meet the required values before applying. In addition, at the end of the compost process, the concentration of $\mathrm{NH}_{4}-\mathrm{N}$ should be lower than that of $\mathrm{NO}_{3}-\mathrm{N}$. As mentioned above, $\mathrm{NH}_{4}-\mathrm{N}$ positively correlated with the moisture content in the summer chicken manure and alkalinity in the winter chicken manure. Therefore, the $\mathrm{NH}_{4}-\mathrm{N}$ concentration may be decreased by reducing the moisture content in the summer chicken manure and alkalinity in the winter chicken manure.

\section{Conclusions}

The alkalinity content and COD concentration in winter chicken manure were higher than those of the summer chicken manure. In the summer chicken manure, no correlations were observed between alkalinity and almost all other parameters; TOC was correlated with the other parameters except for $\mathrm{NO}_{3}-\mathrm{N}$, while $\mathrm{COD}$ was correlated with the $\mathrm{C} / \mathrm{N}$ ratio. In the winter chicken manure, a significant, negative correlation was observed between alkalinity and the $\mathrm{C} / \mathrm{N}$ ratio but positively correlated with $\mathrm{NH}_{4}-\mathrm{N}$ and T-N. The moisture content of the summer manure was positively correlated with almost all of the other parameters, while it was negatively correlated with almost all of the other parameters in the winter season. According to the criterion of the $\mathrm{C} / \mathrm{N}$ ratio, chicken manure from farms in South Korea indicated the potential for good quality compost. However, the composted chicken manure was immature and unstable when considering the criteria of the $\mathrm{NH}_{4}-\mathrm{N} / \mathrm{NO}_{3}-\mathrm{N}$ ratio and the $\mathrm{NH}_{4}-\mathrm{N}$ concentration.

\section{References}

1. Mohamed AM, Sekar S, Muthukrishnan P. Prospects and potential of poultry manure. Asian J. of Plant Sci. 2010;9(4):172-182.

2. Wang K, Li X, He C, et al. Transformation of dissolved organic matters in swine, cow and chicken manures during composting. Bioresour. Technol. 2014;168: 222-228.

3. Bouwman AF, Booij H. Global use and trade of feedstuffs and consequences for the nitrogen cycle. Nutr. Cycl. Agroecosys. 1998;52:26-267.

4. Chau LH. Biodigester effluent versus manure, from pigs or cattle, as fertilizer for duckweed (Lemna spp.). Livest. Res. Rural. Dev. 1998;10:1-9.

5. Magagula NEM, Ossom EM, Rhykerd RL, Rhykerd CL. Effects of chicken manure on soil porperties under sweetpotato [Ipomoea batatas (L.) Lam.] culture in Swaziland. American-Eurasian J. of Agronomy 2010;3:36-43.

6. Ghanbarian D, Youneji S, Fallah S, Farhadi A. Effect of broiler litter on physical properties growth and yield of two cultivars of cantaloupe (Cucumis melo). Int. J. of Agric. \& Biology. 2008;10:697-700.

7. Dikinya O, Mufwanzala N. Chicken Manure-Enhanced Soil Fertility and Productivity: Effect of Application Rates. J. of Soil Sci. and Environ. Manage. 2010;1:46-54.

8. Aboutayeb R, Mohamed E, Zhor A, Badr F, Yahya K. The use of composted poultry manure as an organic amendment: Effects on soil physicochemical properties and Mentha Spicata L. yield. Int. J. of Advanced Res. 2014;2:1109-1119.

9. Niu Q, Hojo T, Qiao W, Qiang H, Li Y. Characterization of methanogenesis, acidogenesis and hydrolysis in thermophilic methane fermentation of chicken manure. Chem Eng. J. 2014;244:587-596.

10. Pierre G, Chilonda P, Franceschini G, Menzi H. Geographical determinants and environmental implications of livestock production intensification in Asia. Bioresour. Technol. 2005;96: 263-276.

11. Liao Q, Huang D, Jiang Z, et al. Estimation of production amount of livestock and poultry manure and environmental impact assessment in Guangxi. Asian Agric. Res. 2013;5:93-96.

12. Bernal MP, Paredes C, Sáchez-Monedero MA, Cegarra J. Maturity and stability parameters of composts prepared with a wide range of organic wastes. Bioresour. Technol. 1998;63: 91-99.

13. Cambardella CA, Richard TL, Russell A. Compost mineralization in soil as a function of composting process conditions. European J. of Soil Biology 2003;39:117-127.

14. Moral R, Paredes C, Bustamante MA. Marhuenda-Egea F., Bernal M. P. Utilisation of manure compost by high-value crops: Safety and environmental challenges. Bioresour. Technol. 2009;100:5454-5460.

15. Guo R, Li G, Jiang T, et al. Effect of aeration rate, C/N ratio and moisture content on the stability and maturity of compost. Bioresour. Technol. 2012;112:171-178.

16. MOE. The Korean Standard Test (KST) Methods for waters. Gwachun, Kyunggi: Korean Ministry of Environ; 2008.

17. APHA. Standard Method for the Examination of water and wastewater. Washington D. C: American Public Health Assoc; 1999.

18. Kimura A, Sato S, Kato T, et al. Relationship between $\mathrm{pH}$ and Temperature in the ruminal fluid of cows, based on a Radio-Transmission pH-Measurement System. The J. of 
Veterinari. Medical Sci. 2012;74:1023-1028.

19. Wenche B, Carlos D, Rune B. Effects of psychrophilic storage on manure as substrate for anaerobic digestion. BioMed. Res. Int. 2014;2014:1-8.

20. Schroder JJ, Scholefield D, Cabral D, Holfman G. The effects of nutrient losses from agriculture on ground and surface water quality: the position of science in developing indicator for regulation. Env. Sci. \& Policy. 2004;7:15-23.

21. Curley EM, O’Flyenn MG, Macdonel KP. Nitrate leaching losses from Miscanthus x giganteus: impact of ground water quality. J. of Agronomy 2009;8:107-112.

22. Masarirambi MT, Sibandze N, Wahome PK. Effect of kraal manure application rates on growth and yield of wild okra (Corchorus olitorious L) in a sub-tropical environment. Asian J. of Agric. Sci. 2011;4:89-95.

23. Masarirambi MT, Dlamini P, Wahome PK, Oseni TO. Effects of chicken manure on growth, yield and quality of lettuce (Lactuca sativa L.) 'Taina' under a lath house in a semi-arid sub-tropical environment. American-Eurasian J. Agric. $\mathcal{E}$ Environ. 2012;12:399-406.

24. Bertoldi DM, Vallini G, Pera A. The biology of composting: a review. Waste Manage. Res. 1983;1:157-176.

25. Jusoh MLC, Manaf LA, Latiff PA. Composting of rice straw with effective microorganisms (EM) and its influence on compost quality. Iranian J. of Environ. Health Sci. \& Eng. 2013;10:17.

26. Zmora-Nahum S, Markovitch O, Tarchitzky J, Chen Y.
Dissolved organic carbon (DOC) as a parameter of compost maturity. Soil Biology. \& Biochemist. 2005;37:2109-2116.

27. Larney FJ, Hao X. A review of composting as a management alternative for beef cattle feedlot manure in southern Alberta, Canada. Bioresour. Technol. 2007;98:3221-3227.

28. Iglesias-Jiménez E, Pérez-García V. Determination of maturity indices for city refuse composts. Agric. Ecosystems. \& Environ. 1992;38: 331-343.

29. California Compost Quality Council (CCQC). Compost Maturity Index. [Internet] Nevada, CA: c2001. [cited 2015 Apr 15]. Available from : http://www.calrecycle.ca.gov/organics/ products/quality/compmaturity.pdf.

30. Sánchez-Mondero MA, Roig A, Paredes C, Bernal MP. Nitrogen transformation during organic waste composting by Rutgers system end its effects on $\mathrm{pH}, \mathrm{EC}$ and maturity of the composting mixtures. Bioresour. Technol. 2001;78:301-308.

31. Zucconi F, de Bertoldi M. Compost specifications for the production and characterization of compost from municipal solid waste. Elsevier Applied Sci. 1987;30-50.

32. Bernal MP, Alburquerque JA, Moral R. Composting of animal manures and chemical criteria for compost maturity assessment. A review. Bioresour. Technol. 2009;100:5444-5453.

33. Dev R, Antil RS. Evaluation of maturity and stability parameters of composts prepared from agro-industrial wastes. Bioresour. Technol. 2011;102:2868-2873. 